\title{
Group Investigation (GI) on Students Descriptive Writing
}

\author{
Nurfatihah Pohma1), Suhaila Waeji ${ }^{2}$ ) \\ 1) Raman Siriwit Junior High School, Yala, Thailand \\ 2)Tarbiatulwatan Mulniti School, Mueang Yala, Thailand \\ 1)Nurfatihahpohma6@gmail.com, 2)Suhailawaeji33@gmail.com
}

\begin{abstract}
The objective of this study was to investigate whether Group Investigation increased first-grade students' descriptive writing at Raman Siriwit Junior High School, Thailand. This study is quantitative were pre-test and post-test used to collect the data. The writers applied a t-test to analyze the data. Based on the Equal variance column, in obtained $t$-count scores is 11.808 by computing table scores $n 1+n 1-2=23+23-2=$ 44 , then obtained t-table score is 2.05 and significant score is 0.000 . Because the score of $\mathrm{t}$-count is $11.808>\mathrm{t}$-table 2.05 and the significant score is $0.000<\alpha=0.05$, so that $\mathrm{H} 0$ is rejected and Ha is accepted. This means that the pretest writing score compared to the posttest writing score is different. This means that there are significant differences in writing pretest scores with posttest scores after the Group Investigation method. Group Investigation increased first-grade students' descriptive writing at Raman Siriwit Junior High School, Thailand.
\end{abstract}

Keywords: Group Investigation, descriptive writing, teaching writing.

Citation APA Style: Pohma, N., \& Waeji, S. (2020). Group Investigation (GI) on Students Descriptive Writing. English Language in Focus (ELIF), 2(2), 103-110.

\section{INTRODUCTION}

$\mathrm{E}$ nglish as one of the subjects that play an important role in schools. Besides, English is often used in books, journals, or articles about knowledge and technology. Therefore, to develop science, knowledge, and technology, and communicate with people from other countries, English is taught from junior high schools until universities. It is taught to give students the four fundamental skills in written and verbal comprehension, namely including reading, writing, speaking, and listening. Four language skills (also known as four language learning skills) are a set of four capabilities that allow one to comprehend and produce spoken language for proper and effective interpersonal communication. In the context of first-language acquisition, the four skills are most often acquired in the order of listening first, then speaking, then possibly reading and writing. For this reason, these capabilities are often called LSRW skills.

Writing is an activity of expressing one's thoughts, ideas, and feelings of a person expressed in written language. In another sense, writing is an 
activity to express thoughts and feelings in a written form that is expected to be understood by the reader and serves as an indirect means of communication. According to Nystrand (1989, p. 75), writing is a matter of elaborating the text according to what the writer can reasonably assume that reader knows and expects. This means that writing is an activity to share information, which is understandable for the readers.

Randal (2004, p. 160) explains that writing is an ability to make a form of words that in general, may have a higher truth value than the fact that it has set it down. It means that the product of writing should be truly accepted by the readers. Besides, it must contain meaningful values so that the readers can get the benefits from the writing. Besides, Harmer (2004, p. 86) explains that writing is a process that what we write is often heavily influenced by the constraints of genres, and then these elements have to be present in learning activities. It means that writing can't be separated from genres especially in teaching-learning activities of writing.

The teaching of writing was divided into separate stages to reflect the various moments involved in the process of writing then perhaps many of the obstacles experienced by both students and teachers could be addressed. Writing practice in the classroom however, is often taken up for display purposes, to assess if students have learned language structures taught in class and for examination purposes. Here, the teacher is concerned with the final product of writing: an essay, a report, an article or story, based on standard models; that these meet the Standard English rhetorical style; and are grammatically correct and organized in a conventional manner (Brown as cited in Elbow, 2006).

Several types of writing are mentioned by some linguists, and one of them becomes the focus of the study, descriptive writing. According to Houp and Pearsall in Vesilind (2007), descriptive writing aims to help the reader visualize, in detail, the character, event, place, or all of these things at once. The author might describe the scene in a sensory manner. This means that the author does not tell the reader what was seen, felt, tasted, smelled, or heard. Rather, he describes something that he experienced and, through his choice of words, makes it seem real. In other words, descriptive writing is vivid, colorful, and detailed (Rescue Writing, 2017).

Good descriptive writing creates an impression in the reader's mind of an event, a place, a person, or a thing. The writing will be such that it will set a mood or describe something in such detail that if the reader saw it, they would recognize it. To be good, descriptive writing has to be concrete, evocative and plausible (Your Dictionary, 2015). Descriptive text writing is not difficult to write and many people find it easy to write, especially those who have a good imagination and can print it in the form of a work. The items at the venues or parties, that the author has taken for the reader to make imagination and portray the narrative during the readable period.

According to Kane (2000, p. 352) description is about sensory experience how something looks, sounds, tastes. Mostly are about visual experience, but 
the description also deals with other kinds of perception. Besides, Harwell and Dorril in Hyland (2004) explain that the twofold purpose of the description is to share sense impressions and to record thoughts and feelings stimulated by those impressions, in other words, they are both an objective relaying of sense data and a subjective interpretation of that data.

Buscemi (1990, pp. 78-79) explains that description is a kind of writing used for presenting a verbal portrait of a person, or thing. This writing is used when the writers want to give details information and to make vivid writing. In other words, it used to develop a picture of "what is look like" it seems that the interpretation of the writer will color the result of the writing. It is because the writer does not only give the information itself, but also creates a certain image of the object.

Hyland (2004, p. 214) explains that descriptive text is a text, which has a social purpose to give an account of the imagined or factual event. Hyland explains more about the description that it tends to use present tense, and description makes use of "be" and "have". In addition, Cowie (1983) explains that descriptive presents the appearance of things that occupy space, whether they are objects, people, buildings, or cities. The aim of descriptive is to convey the reader what something looks like. It attempts to paint a picture with words.

In reality, the problem of writing English is that students do not practice writing. The students assume that writing skills are perceived as the most difficult skills than others (Hadi \&
Anggaira, 2017). To overcome the students' descriptive writing, one method that can be implemented is Group Investigation. It is an organizational approach that allows a class to work actively and collaboratively in small groups and enables students to take an active role in determining their own learning goals and processes. Group Investigation method requires the students to form small interest groups, plan and implement their investigation, synthesize the group members' findings, and make a presentation to the entire class.

Group Investigation is cooperative learning. The emphasis is on the working atmosphere of democracy. Focus on the experience, ability and needs of the learner. According to (Zingaro, 2008, p. 1) Group Investigation, students form interest groups within which to plan and implement an investigation and synthesize the findings into a group presentation for the class. Group structure is defined as the layout of a group. It is a combination of group roles, norms, conformity, workplace behavior, status, reference groups, status, social loafing, cohorts, group demography and cohesiveness.

Student interest groups provide extracurricular activities for students to participate in and build meaningful networks with others who have similar interests. These extracurricular activities are educational, intellectual, interdisciplinary, cultural and social and help students develop leadership and workplace skills, collaborative relationships with others, and a sense of one's identity. Sharan in Jacobs (2008) explains that Group Investigation is a 
method for classroom instruction in which students work collaboratively in small groups to examine, experience, and understand their topic of study. Group Investigation is designed to appeal to all facets of the students' abilities and experience relevant to the process of learning, not just to the cognitive or social domains. It provides educators with an approach to the conduct of teaching and learning in school that differs significantly from traditional instruction.

Group Investigation is not simply another technique for improving instruction so that students can learn more at a faster pace while teaching and the classroom environment remain largely as they were. To comprehend fully the goals and meaning of the group investigation method, it is imperative to examine the, intellectual, pedagogical, and psychological foundations upon which this method is based. The teacher's general role is to make the students aware of resources that may be helpful while carrying out the investigation.

In Group Investigation, pupils progress through six steps. The steps of using Group Investigation (GI) as follow 1) Topic Selection, students choose a specific sub-topic within the field of certain common problems, which are usually explained by the teacher. Then, students are organized into small groups consisting of task-oriented two to six people. The composition of the hetero generous groups both academically and ethically. 2) Cooperative Learning, students and teachers plan procedures, tasks, and specific learning objectives following sub-sub topics selected in step.
3) Implementation, students implement a plan formulated in step 2. Learning should involve a variety of activities and skills and should lead students to a variety of sources inside and outside of school. The teacher follows closely the development of each group and offer help when needed. 4) Analysis and Synthesis, students analyze and evaluate information obtained during step 3 and plan for how this information can be summarized by drawing to be displayed or presented to classmates. 5) Presentation of the final product, some or all groups in the class give an interesting presentation on topics to make each other involved in his work and achieve a broader perspective about a topic. The teacher coordinates the presentation group. 6) Evaluation, in some cases, the groups follow up the different aspects of the same topic. The students and the teacher evaluate the contribution of the whole work in each group. The evaluation included individual and group assessment or both of them (Sharan \& Sharan, 1990; Tuckman, 1965).

\section{RESEARCH METHODOLOGY}

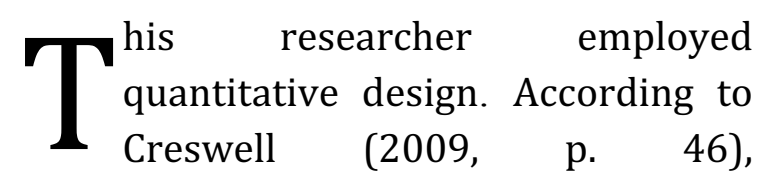
"quantitative is a type of educational research in which the researcher decides what the study, asks specific questions, collected quantifiable data from participants, analyze these number using statistics, and conducts the inquiry in an unbiased, objective manner". Quantitative is one of the educational research methods that explain the result of research that uses the numerical data analyzed statically. 
In this quantitative research, the writer used a quasi-experimental design with one group pretest and posttest. The pre-experimental design, which is used one experimental group covers, pre-test, treatment and post-test. Solomon \& Lessac (1968) explained that "this design has one group, pre-test, treatment, posttest. This design has no control group and random assignment". In this study, the experimental group was firstly given a pre-test before the treatment. Then, the group was taught descriptive writing by group investigation. In teaching writing and learning process, Group Investigation was used as teaching media. After the treatments given to this group, the post-test of descriptive writing was given.

Table 1. Pre-test and post-test preexperimental research design.

\begin{tabular}{lccc}
\hline Sample & Pre-test & Treatment & Post-test \\
\hline $\begin{array}{l}\text { Experime } \\
\text { ntal } \\
\text { group }\end{array}$ & $\mathrm{Sc} 1$ & $\mathrm{X} 1, \mathrm{X} 2$ & $\mathrm{Sc} 2$ \\
\hline
\end{tabular}

Note:

Sc1 : Students writing the descriptive text of the experimental group in the pre-test.

$\mathrm{X}$ : Treatment teaching descriptive writing by group investigation

Sc2 : Students writing the descriptive text of the experimental group in the post-test.

In collecting the data, this research will do teacher treatment of the students' writing to see whether there is any difference between the students' achievement before the implementation of the action (pre-test) and after the implementation of the action (post-test). Pre-test, it refers to a measure or test given to the subject before the experimental treatment this test was given to know the basic competence of those 27 students to know their prior ability before they get the treatment. In this test, the students were asked to write a topic about "Vocabulary" and were given five guide questions to make a descriptive text. This question was taken from an English book for students "English for international communication", published by (Richards, Hull, \& Proctor, 2005).

Post-test, it was used to measure students' skills after the treatment to know their progress after they got treatment. Before having a post-test, the students got treatment. Treatment here means that, the writer in teaching descriptive writing. In the post-test, the writer gave a topic about "Thing". The test was also about descriptive writing. Similar to the pre-test, five guide questions were also provided to the student to compose the test. In assessing the test, a rubric for assessing descriptive writing from Brow (2007) was used by the writer.

\section{RESEARCH FINDINGS}

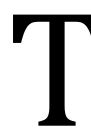

he results of the descriptive writing pretest of 26 first-grade students at Raman Siriwit Junior High School above shows that of the 26 students 3 students do not follow the pretest descriptive writing. Only 23 students who followed the test of descriptive writing that obtained minimum pretest score is equal to 19 , the maximum pretest score is 58 , the mean score of the pre-test is 39.26 , the score of the mode is 39 with the standard deviation score is 11.258.

The description of descriptive writing group score and the graphic 
score of 23 students' first-grade Junior High School are as follows:

Looking for the biggest and smallest scores

The biggest score $=58$

The smallest score $=19$

Find range scores $(\mathrm{R})$

$\mathrm{R}=$ the biggest score - the smallest score

$$
\mathrm{R}=58-19=39
$$

Looking for the number of Classes (BK)

$$
\begin{aligned}
& \mathrm{BK}=1+3,3 \log n \\
& \mathrm{BK}=1+3,3(1,36) \\
& \mathrm{BK}=1+2,996 \\
& \mathrm{BK}=4
\end{aligned}
$$

Looking for class length scores (i)

$$
\mathrm{I}=\mathrm{R} / \mathrm{BK}=39 / 4=10
$$

The posttest writing test results of 26 first-grade students at Raman Siriwit Junior High School above shows that the 26 students 3 students do not follow the pretest. Only 23 students, the minimum posttest score is 19, the posttest maximum is 58 , the posttest average is 39.26 , and the mode score is 39 with the standard deviation score of11.258.

The description of the descriptive writing score and graphic score posttest of 23 students is as follows:

Looking for the biggest and smallest scores

$$
\begin{aligned}
& \text { The biggest score }=: 58 \\
& \text { The smallest score }=: 89
\end{aligned}
$$

Finding range scores (R) smallest score

$$
\mathrm{R}=\text { the biggest score - the }
$$

$$
\mathrm{R}=58-19=31
$$

Looking for the number of classes (BK)

$$
\begin{aligned}
& \mathrm{BK}=1+3,3 \log \mathrm{n} \\
& \mathrm{BK}=1+3,3(1,36) \\
& \mathrm{BK}=1+2,996 \\
& \mathrm{BK}=4
\end{aligned}
$$

Looking for class length scores (i)

$$
\mathrm{I}=\mathrm{R} / \mathrm{BK}=31 / 4=8
$$

Based on the calculation of Tcount score of pretest and posttest obtained score Tcount $=11,808$ and Ttable score $=2,10$ $($ Ttabel $=n 1+n 2-2=44)$. With the help of the SPSS 22 program obtained the same results with manual calculations.

\section{CONCLUSION}

$\mathrm{n}$ this study, the authors can
conclude and prove the problem
formulation as follows: There are differences in the score of writing pretest and posttest shows the average score of pretest writing amounted to 39.261 and the average posttest score of 75.347 with the average difference between the two groups was 36.087. Thus, it can be concluded that Group Investigation as a teaching method is effective in teaching descriptive writing. This teaching method gave positive contributions and better results in descriptive writing.

\section{REFERENCES}

Buscemi, S. V. (1990). A Reader for Developing Writers. New York: McGraw-HillCompanies, Inc.

Cowie, J. R. (1983). Automatic Analysis of Descriptive Texts. Proceedings of the First Conference on Applied Natural Language Processing, 123. https://doi.org/10.3115/974194.97 4218

Creswell, J. W. (2009). Research Design Qualitative, Quantitative, and Mixed Methods Approaches. London: SAGE Publications, Inc.

Elbow, P. (2006). Do We Need a Single Standard of Value for Institutional Assessment? An Essay Response to Asao Inoue's "Community-Based Assessment Pedagogy." Assessing Writing, 11(2), 81-99. 
https://doi.org/10.1016/j.asw.2006 .07 .003

Hadi, M. S., \& Anggaira, A. S. (2017). The Use of Mobile Assisted Language Learning (MALL) In Teaching Writing. 15th Asia TEFL \& 64th TEFLIN International Conference. Retrieved from https://www.academia.edu/363167 86/Asia_TEFL_full_paper

Harmer, J. (2004). How to Teach Writing. New York: Longman.

Hyland, K. (2004). Genre and Second Language Writing. Ann Arbor, MI: The University of Michigan Press.

Jacobs, G. (2008). A Review of "Group Investigation and Student Learning: An Experiment in Singapore Schools." International Research in Geographical and Environmental Education, 17(4), 372-375. https://doi.org/10.1080/10382040 802401680

Kane, T. S. (2000). Essential Guide to Writing. Oxford.

Nystrand, M. (1989). A Social-Interactive Model of Writing. Written Communication, 6(1), 66-85. https://doi.org/10.1177/07410883 89006001005

Randal, H. (2004). Literacy an Introduction. Edinburgh: Edinburgh University.

Rescue Writing. (2017). Writing Descriptive Text. Retrieved April 5, 2019,

from https://rescuewriting.org/featured/ writing-descriptive-text/

Richards, J. C., Hull, J., \& Proctor, S. (2005). Interchange: English for international communication 1. Cambridge: Cambridge University Press.

Sharan, Y., \& Sharan, S. (1990). Group Investigation Expands Cooperative Learning. Educational Leadership, 47(4), 17-21. Retrieved from https://eric.ed.gov/?id=EJ400492

Solomon, R. L., \& Lessac, M. S. (1968). A Control Group Design for Experimental Studies of Developmental Processes. Psychological Bulletin, 70(3), 145150. Retrieved from https://doi.org/10.1037/h0026147

Tuckman, B. W. (1965). Developmental Sequence in Small Groups 1. Psychological Bulletin, 63(6), 384399.

Vesilind, P. A. (2007). Public Speaking and Technical Writing Skills for Engineering Students. USA: Lakeshore Press.

Your Dictionary. (2015). Descriptive Text Examples. Retrieved April 5, 2019, website:

https://examples.yourdictionary.co $\mathrm{m} /$ descriptive-text-examples.html

Zingaro, D. (2008). Group Investigation: Theory and Practice. Retrieved from http://www.danielzingaro.com/gi.p df 
English Language in Focus (ELIF), 2(2), 103-110. https://jurnal.umj.ac.id/index.php/HLIF 